\title{
探索建立鄱阳湖生态经济区区域生态补偿机制 推进江西生态文明先行示范区建设
}

\author{
涂文婷 \\ 江西省直机关工委党校 江西南昌 330077 \\ DOI 号:10.18686/bd.v1i4.355
}

[ 摘 要] 生态文明建设是中国特色社会主义事业的重要内容。党的十八大提出大力推进生态文明建设,加大自然生态系 统和环境保护力度, 扩大森林、湖泊、湿地面积, 保护生物多样性。省委、省政府对生态文明建设高度重视, 始终坚持"既要金 山银山, 又要绿水青山" 的发展理念, 提出到 2020 年要将江西建设成为全国生态文明先行示范省, 其中建立大湖流域生态 保护与科学开发典范区是三大示范定位之一。

[关键词］鄱阳湖生态经济区; 生态补偿机制

鄱阳湖是我国第一大淡水湖, 也是长江干流重要的调 蓄性湖泊, 在中国长江流域中发挥着巨大的调蓄洪水和保 护生物多样性等特殊生态功能, 是我国十大生态功能保护 区之一,也是世界自然基金会划定的全球重要生态区之一, 对维系区域和国家生态安全具有重要作用。鄱阳湖生态经 济区以江西省 30\%的国土面积, 承载了全省近 50\% 的人 口, 创造了 $60 \%$ 以上的经济总量, 具有良好的经济发展基 础和重要的生态保障作用。上世纪 80 年代以来, 随着人口 增长和工业化、城镇化进程的加快, 鄱阳湖区生态环境遭到 严重破坏, 连续多年出现历史罕见低水位, 水体污染日益加 重, 生态环境日渐衰退, 湿地功能不断退化, 湖区土地严重 沙化, 甚至出现了江南最大沙地, 整个区域面临日益严峻的 水污染威胁和湿地退化现象。鉴于鄱阳湖生态经济区面临 的严峻问题, 必须积极探索生态功能保护区办法, 尽快建立 生态补偿机制, 实施必要的生态补偿政策。

1、建立鄱阳湖区域生态补偿机制的重大意义
生态补偿机制, 是依据生态系统服务价值、生态保护成 本、发展机会成本, 综合运用行政手段和市场手段,为保护 生态环境、促进人与自然的和谐, 而调整生态环境保护和建 设相关方利益关系的环境经济政策。

1.1 、建立生态补偿机制是落实科学发展观、实现区域 协调发展的重大战略选择。中国经济和生态的矛盾日益尖 锐,生态资源和经济水平的空间分布不均, 造成地区间可持 续发展的不平衡, 造成资源型产品生产和消费空间的分离, 形成生态功能区往往与经济不发达区相重叠。作为公共产 品或公共服务,生态环境具有显著的效益外溢性特征。经济 欠发达地区为生态受惠区 (即经济发达地区) 提供大量的生 态服务, 却由于公共产品的外部性特征而无法得到应有的 补偿, 极大地挫伤了生态功能区保护生态环境的积极性。要 解决这类问题, 就必须建立生态补偿机制。党的十八大报告 中强调, 要“建立反映市场供求和资源稀缺程度、体现生态 价值和代际补偿的资源有偿使用制度和生态补偿机制”。 
1.2、鄱阳湖生态环境和生态平衡敒关长江中下游地区 乃至全国生态安全、粮食安全和用水安全。鄱阳湖是我国最 大的“大陆之肾”。目前鄱阳湖面临着巨大的生态、环境压 力, 严重影响了鄱阳湖生态环境和生态平衡, 这不仅影响到 江西经济可持续发展, 也严重影响了长江中下游地区乃至 全国生态安全、粮食安全和用水安全。因此,恢复鄱阳湖生 态功能, 维护生态系统可持续发展和利用, 促进鄱阳湖生态 经济区的发展，建立鄱阳湖区域生态补偿机制不仅具有必 要性,而且具有紧迫性。

1.3 、建立鄱阳湖区域生态补偿机制是国家区域重大发 展战略的迫切需要

《鄱阳湖生态经济区规划》获得国务院批准, 标志着鄱 阳湖生态经济区建设上升为国家战略。建设鄱阳湖生态经 济区就是要探索我国大湖流域生态、经济、社会协调发展、 综合开发的新模式, 国家已经将鄱阳湖生态经济区确立为 建立生态补偿机制的试点区域, 要求率先建立生态补偿机 制, 进而为全面建立生态补偿机制提供经验。

\section{2、我省推进以鄱阳湖生态经济区为主的生态补偿机制 建设的探索和实践}

近年来,省委、省政府在党中央、国务院的正确领导下， 深人贯彻落实科学发展观, 大力实施“生态立省、绿色崛起” 战略,积极探索符合江西实际的科学发展、进位赶超、绿色 崛起的路子。目前,全省森林覆盖率达 $63.1 \%$, 居全国第二; 地表水监测断面达标率达到 $80.7 \%$, 高出全国 30 多个百分 点; 饮用水源地水质达标率 $100 \%$, 翻阳湖注人长江水质保 持在三类以上; 11 个设区城市环境空气质量全部达到国家 二级标准。在加强生态建设和环境保护过程中, 着重从五个 方面对生态补偿机制进行了积极探索。

2.1、建立了流域水环境保护生态补偿机制。赣江、抚 河、信江、饶河、修河是我省五大河流, 全部汇人鄱阳湖流人 长江; 东江则是粤港的重要水源地。为保护好鄱阳湖一湖清 水、维护粤港用水安全,先后出台《关于加强“五河一湖”及 东江源头环境保护的若干意见》、《“五河” 和东江源头保护 区生态环境保护奖励资金管理办法》,由省财政每年安排专 项资金采取以奖代补方式对 “五河” 和东江源头保护区给予 生态补偿。

2.2、加大了地方公益林生态补偿力度。2005 年, 省财政 安排 1000 万元启动了地方公益林省级森林生态效益补偿 机制。目前, 全省纳人国家、省级补偿范围的公益林面积达 5100 万亩,其中地方公益林 1900 万亩; 我省公益林的补偿 标准也由最初的每亩 5 元逐步提高到每亩 15.5 元, 大大高 于中央国有林补偿 5 元、集体林补偿 10 元的标准。2013 年, 将公益林补偿标准提高到每亩 17.5 元, 投人生态公益 林补助资金 8.9 亿元。

2.3、实施了重要生态功能区补偿的财政转移支付制 度。自 2009 年起, 我省实施重点生态功能区转移支付。重点 投向:关系国家或区域生态安全,并由中央或省级主管部门
制定保护规划确定的限制和禁止开发的重点生态功能区; 生态外溢性较强、生态环境保护较好的生态功能区; 经国家 或省级批准的其他重点生态功能区。2012 年安排中央补助 资金 9.16 亿元，用于对纳人重点生态功能区内的县（市、 区)进行环境保护和改善民生。

2.4、设立了自然保护区建设奖励政策。从 2011 年起, 省财政设立省级自然保护区专项资金，对省级自然保护区 环境保护实施奖励政策,重点用于支持基础条件好、具有重 要示范意义的省级自然保护区的监管能力项目建设, 主要 包括保护区综合科学考察、珍稀野生物种专项调查和监测、 与保护区相适应的能力建设、保护珍稀物种和保护区生物 多样性的管护设施建设等,资金规模为每年 1000 万元。

2.5 、完善了矿产资源开发生态补偿管理办法。制定了 《江西省矿山环境治理和生态恢复保证金管理暂行办法》, 保证金由矿山企业根据采矿登记的矿区面积、采矿许可证 的有效期、矿种、开采方式以及对生态环境的影响等因素预 提,专项用于矿山环境治理和生态恢复,实行“企业所有, 政 府监管,专款专用”。

\section{3、建立健全鄱阳湖区域生态补偿机制的构思}

3.1、建立健全鄱阳湖区域生态补偿机制的基本原则

3.1.1 坚持“谁开发谁保护、谁破坏谁恢复、谁受益谁补 偿、谁排污谁付费”的原则。

通过对污染者收费，把环境污染的所有外部性成本内 部化, 以达到使环境污染的私人成本等于社会成本, 减小以 至消除厂商因污染带来的超额收益的目的。采取该原则,厂 商就会认识到环境污染是需要付出代价的，任何对环境资 源的耗费都需要付出相应的费用，环境产品的价格并不低 于其他市场商品, 从而自觉地减小或消除对环境的污染。通 过对生态保护者进行补偿, 使环保成果转化为经济效益, 激 励人们更好地保护好生态环境。

3.1 .2 坚持因地制宜、分类指导的原则。

鄱阳湖生态经济区地域广大, 人口众多, 经济发展和群 众生活水平有很大的区别, 流域的情况和流域环保的任 务、目标及其环保优先顺序也不尽相同,生态补偿的目标、 标准也不会一样, 因此,制定的生态补偿机制要采取实事求 是的态度,坚持因地制宣、分类指导的原则,对不同地区、不 同生态类型的生态补偿应有区别,付费的方式、标准和机制 也应有一定区别。

3.1.3 坚持循序渐进,协商共识原则。

建立生态补偿机制是对现有利益格局的调整，涉及到 上下游和不同的地区, 会有很大阻力。另外, 确定补偿标准 的某些依据难以量化，也不可能一步到位。所以,建立鄱阳 湖生态经济区生态补偿机制必须循序渐进, 先易后难, 先少 后多, 具体机制和标准要通过相关责任方的协商来设计, 以 共识为基础, 确保机制落实。

3.1.4 坚持国家指导、地方推动、公众参与的原则。 抓紧出台 “关于开展建立流域生态补偿机制试点的指导意 
见”和“全省流域生态补偿政策和机制工作守则”, 以指导鄱 阳湖生态经济区生态补偿机制试点工作。各地应按照中央 和省委省政府要求, 积极开展试点工作。公众参与是指有关 利益相关者和群众的共同参与, 要让他们参加到建立鄱阳 湖生态经济区生态补偿机制的全过程, 以保证流域生态补 偿机制的公平、公正和透明。

建立生态补偿机制需要强大的资金实力作支撑。应根 据不同地区、不同时期经济社会发展的现实基础, 多渠道、 全方位筹措生态补偿资金, 因地制宜选择补偿模式。既要坚 持政府主导, 不断加大财政投人, 又要积极引导社会各方参 与,拓宽资金来源渠道, 探索市场化补偿的路子。

3.2 、健全鄱阳湖区域生态补偿机制的主体和方式

3.2 .1 生态补偿的主体。

鄱阳湖生态经济区生态补偿的主体主要包括国家补 偿、地方政府补偿、社会补偿、自我补偿四类。

国家补偿是指中央政府对流域生态建设给予的财政拨 款和补贴。对于流域生态环境建设中减少的财政收人, 中央 政府要通过财政转移支付、银行贷款、政策倾斜等渠道给予 补助、支持。由于鄱阳湖流域战略地位十分重要, 国家应加 大对该地区的投人力度, 建立多渠道、多层次、多元化的资 金筹措机制。

地方政府补偿主要指上下游之间政府的补偿。流域上 游的生态保护直接影响到下游地区的生态质量, 下游地区 对上游地区的生态保护努力和机会成本给予相应的补偿。 生态资源由社会共享, 然而通常是欠发达地区却担负着保 护江河上游生态的重任, 在目前生态补偿制度尚未完善的 情况下, 与享受生态效益的下游地区相比, 显然有失公平。 需要通过生态保护补偿机制, 由经济比较发达的下游地区 补偿上游地区。

社会补偿包括除中央之外的各种形式的民间组织、金 融机构、企业集团、环保社团、国外基金等对流域生态建设 的资助和援助。国家应加大对生态建设补偿的宣传, 提高公 众参与的意识, 让全社会都来关心支持生态环境建设。鼓励 建立一些民间生态建设补偿组织, 拟定发售生态建设彩票, 筹集社会资金投人到流域生态建设中。

自我补偿又可称为内部补偿, 是指流域利用自身资源 优势, 结合生态重建, 走多样化经营的道路, 挖掘自身潜力, 增强自身经济造血功能, 提高经济补偿能力。国家既要注重 对生态环境重点保护地区的“输血型” 补偿, 又要注重地方 经济、替代产业的培育和发展, 增强流域自身“造血能力”, 发展地方经济, 增强自我补偿的能力, 建立生态补偿和地方 经济发展的长效机制, 确保生态补偿机制得以持续地对保 护区发挥作用。

3.2 .2 生态补偿的方式。

鄱阳湖生态经济区生态补偿方式主要有政策补偿、实物补 偿、资金补偿、技术补偿、智力补偿等。

(1)政策补偿。
政策补偿是上级政府对下级政府的权力和机会补偿。 受补偿者在授权的权限内, 利用制订政策的优先权和优惠 待遇,制订一系列创新性的政策,在投资项目、产业发展和 财政税收等方面加大对流域的支持和优惠, 促进发展并筹 集资金。利用制度资源和政策资源进行补偿是十分重要的, 尤其是在资金十分贫乏, 经济十分薄弱的鄱阳湖地区更为 重要, “给政策, 就是一种补偿”。

(2) 实物补偿

实物补偿是补偿主体运用物质、劳力和土地等进行补 偿, 解决补偿对象的部分生产要素和生活要素, 改善受补偿 者的生活状况, 增强其生产能力。实物补偿有利于提高物质 使用效率, 如退耕还林的补偿方式, 就是物质补偿, 运用大 量剩余的粮食进行补偿。对鄱阳湖生态经济区输出的水资 源补偿方式,也可以采取实物形式。

(3) 资金补偿。资金补偿是最常见的补偿方式, 对鄱阳 湖生态经济区来说也是最迫切急需的补偿方式。资金补偿 要以生态建设项目引人资金为主, 包括补偿金、捐款、减免 税收、退税、信用担保的贷款、补贴、财政转移支付、贴息等 方式。

(4)技术补偿和智力补偿。鄱阳湖流域生态建设需要有 一批高素质的人才, 包括管理人才、科技人才、高级技术工 人。补偿者通过开展智力服务, 提供无偿技术咨询和指导, 培养(训)受补偿地区或群体的技术人才和管理人才, 输送 各类专业人才, 提高受补偿者生产技能, 技术含量和管理组 织水平, 以使今后运用现代技术搞好流域生态建设。

3.3、建立和完善鄱阳湖区域生态补偿机制的政策建议

3.3.1 应尽快制定出台专门的生态补偿法律法规。加快 生态补偿立法, 将生态补偿机制的主要原则、基本框架(包 括补偿主体、补偿对象、补偿途径、补偿范围、补偿内容、补 偿标准、补偿管理) 及配套措施等以法律形式确定下来, 使 生态补偿从“道义要求”变为“制度约束”, 在公平、合理、高 效的原则下进行。

3.3 .2 建立生态转移支付专项基金。

建立专项资金对鄱阳湖生态经济区生态保护和建设的 行为进行资金补贴和技术扶助, 如新能源建设、生态公益林 补偿、水土保持补贴和农田保护等。也可以由国家从下游地 区获益中提取一定比例的资源费作为专项基金, 返还给鄱 阳湖生态经济区相关部门。

3.3.3 尽快落实国家重点湿地 (鄱阳湖湿地) 生态补偿 政策。

鄱阳湖是我国最大的淡水湖、唯一没有富营养化的湖 泊、唯一的世界生命湖泊网成员, 经鄱阳湖调蓄注人长江的 水量年均为 1450 亿立方米, 占长江径流量的 $15.5 \%$, 超过 黄河、海河和淮河人海水量的总和, 承担着保障长江中下游 水生态安全的重要使命。鄱阳湖湿地是世界六大湿地, 是西 伯利亚和东欧候鸟重要迁徙地, 湿地面积约 51.81 万公顷, 设有 2 个国家级、 2 个省级、14 个县级自然保护区，在我国 